\title{
Téoros
}

Revue de recherche en tourisme

\section{Tourism Development in the Northern Periphery}

\section{Jan Lundgren}

Volume 6, numéro 1, mars 1987

Tourisme et transports

URI : https://id.erudit.org/iderudit/1080521ar

DOI : https://doi.org/10.7202/1080521ar

Aller au sommaire du numéro

Éditeur(s)

Université du Québec à Montréal

ISSN

0712-8657 (imprimé)

1923-2705 (numérique)

Découvrir la revue

Citer cet article

Lundgren, J. (1987). Tourism Development in the Northern Periphery. Téoros, 6(1), 13-19. https://doi.org/10.7202/1080521ar d'utilisation que vous pouvez consulter en ligne.

https://apropos.erudit.org/fr/usagers/politique-dutilisation/ 


\title{
Tourism Development in the Northern Periphery
}

\author{
by Jan Lundgren*
}

\section{Tourist travel and the periphery}

Tourism has always been associated with movement over space, which makes it a highly geographic subject matter, open to the application of numerous geographic concepts. In addition, the linking of origin and destination places produce strong directional characteristics in the travel move- ment. Thus, the bulk of these movements connect major, more centrally located, generating and receiving core areas at high levels of metropolitan travel interaction. In contrast to the above-mentioned spatiallocational concentration there also exists a distinct centrifugal travel flow, in which the diffusion of tourists from a generating core area is directed toward less inhabited destination zones, where the dominant attractions are the degree of non-urban
W. Christaller in his observations of tourist movements on the European continent ${ }^{[2]}$. Although he recognized the existence of fairly centrally located tourist areas - the Alps, the Rhine Valley etc - his focus was upon the periphicity of the flow pattern the examples ranging from the broad general north-south characteristics in the movements, to the centrifugal features as in the case of popular castal destinations in Denmark along the English Channel, as well

\section{Graphique 1}

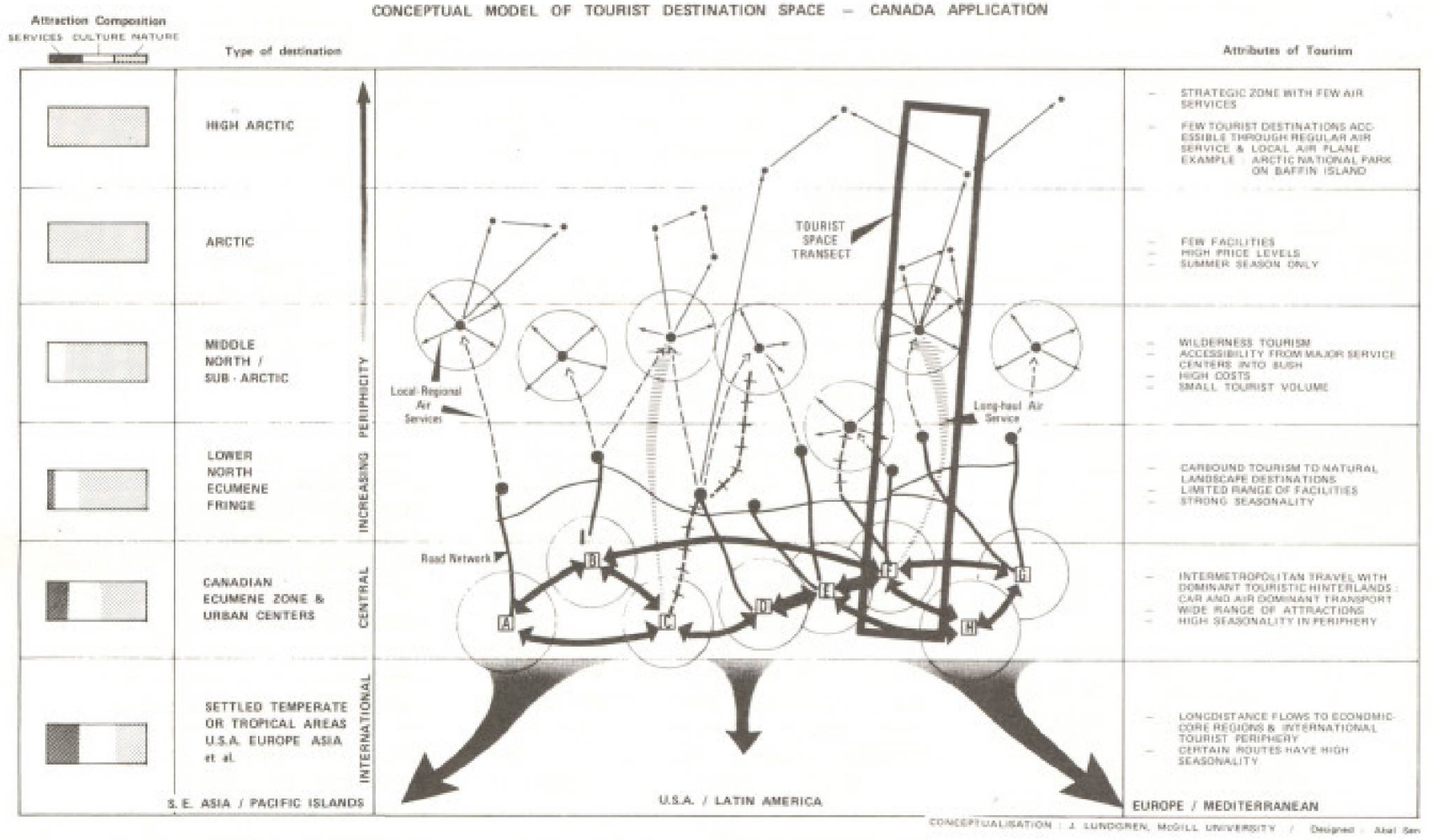

occurrence in the environment, the exoticism associated with foreign, less familiar culture, the dominance of physical landscape features having a high popular recreational appeal or a unique statut - the beautiful warm-water beach zone, the imposing grand canyon or waterfall, the montain zone which attracts the climber or the skier. This functional, more peripheral, but distinct tourist space was first discussed by as in extreme Mediterranean destinations. such as Sicily. He made the observation that tourist intensity levels for many of these subregions can be very high and that the bulk of the visitors come from industrial-metropolitan cores on the continent, or from more peripheral, high income countries, such as Sweden. The vacation pattern tended to have a strong centrifugal thrust in a peripheral direction. 


\section{Canadian tourist space attributes}

Applying Christaller's tourist space with its peripheral attributes to Canadian oonditions makes for both interesting and contrasting comparisons, which go a long way in explaining some features, as well as some constraints. These have been incorporated in the Conceptual circulation model of tourist destination space: Canada application. (fig. 1).

The most significant aspect influencing the functional characteristics of Canadian tourist space in general and its northern sector in particular pertains to the population - land ratio. The model suggests this in its emphasis of a distinct east-west travel flow, positioned well within the Canadia ecumene, and a product of the more or less linear urban-economic system close to the US border. This corridor contains the bulk of tourist travel market demand, which the model suggests is focussed upon the metropolitan areas acting both as generators and receivers. The same travel space also contains the bulk of the tourist supply elements - accomodation, entertainment, food services, transport, cultural historic attractions, a substantial amount of outdoor recreation provisions (manmade and nature- provided)- most within easy reach for the vacationists, who mostly travel by car; distinct vacation hinterlands surround the metropolitan areas- the Quebec City and Montreal Laurentians, the Canadian Shield country and Georgia Bay north of more heavily settled parts of Ontario, the fishing lodge zonesnortheast of Winnipeg and north of Regina-Saskatoon, and further west, the Rocies within driving distance from the Calgary area.

In sharp contrast to the "central spine" in the model stands the more distinct, truly peripheral areas further to the north; it is reasonable to assume that tourist intensity declines quite sharply with distance, when you move into zones not conveniently accessible by car. The difference from the European periphery is more accentuated and is most strongly seen in the dissappearance, in practical terms of human settlement of substance, except for the odd, smaller indigenous villages, a few government administration centers, and/or the mining towns with their limited lifespans. In terms of attractions we can observe a quickly changing "mix" "as we move from south into the north: the mix/areal unit in southern areas tends to be diverse, with both natural landscape elements and human - cultural features, while the further north you go the more singular, and physical environment =oriented, becomes the attraction mix, which has implications for the market base appraisal: the particular natural landscape attraction, the scenery, the hunting, the fishing caters to a more specialized market (at least at the prices asked for) at the expense of the larger family-based vacation market - Not only does the attraction mix becomes more specialized as you move north but the accessibility level to attractions drops sharply, a function both of attraction mix changes and geographic dimensions: the size of the landscape is so overwhelming that the visitor experience is strongly affected not obly by the geographic scale of physical environment but also by the minuteness of the indigenous settlement and its ways of life. This geographic paradox is a product of a combination of factors, above all the general feeling of isolation experienced by the outsider tem= porarly placed in this wast geographic expanse, combined with the sharply curtailed individual mobility, which makes him strongly dependent upon the settlement. The visitor feels as if she/he is on a small island in a "sea of land", a sensation not different from visiting a small-sized, isolated Pacific atoll island.

Apart for the adverse land-topeople ratio in the Canadian North, the other point to emphasize relates to accessibility within the destination area: overland movements are painfully slow and as a result the regional coverage by the visitor tends to be very nodal; the impact of visitors is felt where they disembark from the ait carrier servicing a particular destination. Thus, tourist transport services tend to deposit the visitor right at the attraction- the fishing river camp, the fjord inlet, the foot of the mountain. The touring potential is practically nonexistant circumstances. - The comparison with the european tourist destination space is revealing and establishes the problem inherent in Canadian tourist travel at large in a nutshell: the geographic dimensions. The european tourist space dimensions are approx. $3400 \mathrm{~km} \times 2400 \mathrm{~km}$, excluding European Russia; for Canada the dimensions are $4000 \times 3200$, with $4 / 5$ of the space practically devoid of human settlement. As a consequence, the lack of spatially contigous transport services and their infrastructure over large tracts of land generating little transport demand makes for difficult transport economics, which is detrimental to tourist travel.

A final consideration when analysing the utility of Canadian tourist space, esp. its northern/arctic periphery, pertains to regional climatic conditions. The eastwest ecumene zone is characterized by both summer and winter seasons conducive to a variety of tourist- related pursuits. For the two southern zones in the tourist space model seasonal temperature amplitudes are on the average 20 degrees and 10 respectively for winter and summer. Thus tourist seasons have a duration of approx. 3 months, which produces a reasonable economy in the tourist trade. The moment you move into more northern zones the tourist seasons are much shorter, which reduces the trade potential for tourist businesses: in the middle of Labrador there are only a few summer weeks of frostfree and icefree conditions; the winter season starts early and does not become benign until April - at a time when the southern travel market potential is fairly domant and hardly geared toward arctic destinations, could it be activated. This market constraint can be contrasted with the northern periphery of European tourist space, primarily the northern areas of Scandinavia, which offers a two months" summer season and a usable winter season from early February to the end of May - thus providing a good basis for a two-season tourist trade, even in the most remote areas.

\section{Changing tourist destination patterns - a product of transport dynamics}

Northbound tourist travel flows are of fairly recent datum due to the limitations imposed by the transport services available over time. An understanding of the attributes of different transport mechanisms used for northern travel is essential in order to explain the extension of the tourist destination gradient over the decades deeper into the North. As basis for discussion of the role of the different modes of transport the reader is referred to fig. 2 which provides some explanation to both exisiting and more historical situations.

\section{A. The Rail*;}

The most critical constraint upon a northbound tourist penetration rested with the east-west orientation of the oldest bulk carrying mode of transport - the railway network. The rail system was developped in response to the need to establish efficient transcontinental passenger and freight services. It was fully operational throughout the country already before 1900 , but had only a marginal impact upon the outdoororiented tourism in northern zones. Nevertheless rail definitely assisted in the development of the first-generation lodge enterprises, as can be seen for instance along the northwestern Ontario-Winnipeg axis and to a degree also in central northern Ontario-middle Quebec. These enterprises were hardly northern, but fit well into the "peripheral" category, as they were distantly located relative to major travel-generating urban centers.

The situation changed in the 1930 's, when the northbound rail-lines to Churchill and Moosonee were opened. A more recent line was made operational in the early 1950 's between Sept Isles and the Labrador mining towns Labrador City, Wabush and Schefferville. Even if the rail system could provide a remarkable passenger transport economization compared to alternatives it did not produce any mass travel northward. It definitely assisted on a substantial scale to the opening up of many outdoor districts far away from major cities. However, the transport constraint imposed upon the 


\section{Graphique 2}

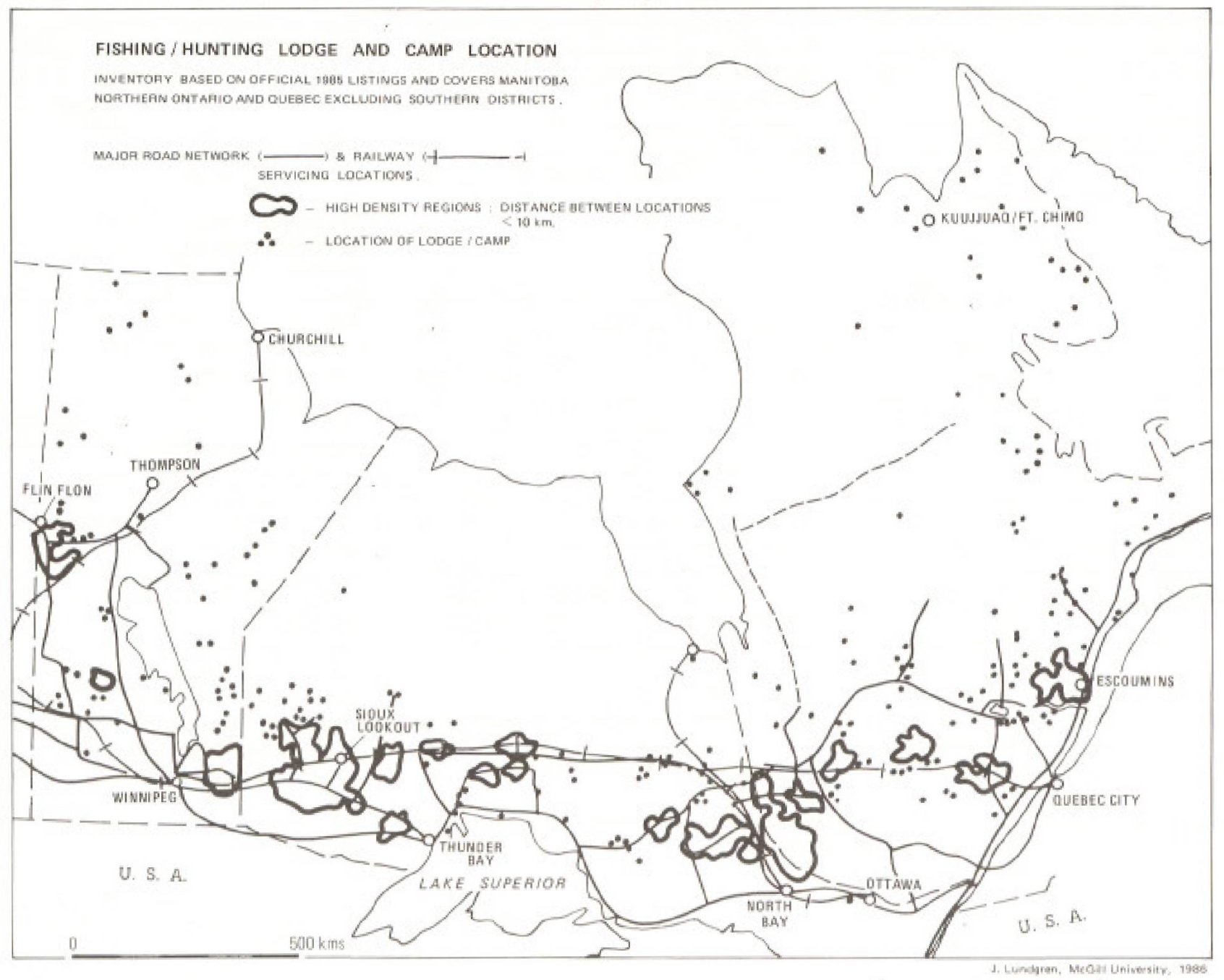

traveller when he disembarked at the railway stop - Parent (Que.), Herst (Ont.) Nakina (Ont.) -was considerable and reduced the amount of surrounding territory he might wish to explore or fish/hunt, as local transport usually was very restricted. -The Ontario Northland Railroad (destination James Bay) was the only line that saw mass tourist travel. In the 1970 's the annual passenger volume had passed 70.000 , of which the bulk were tourists on reasonably priced excursions to the Arctic Sea and the Old Hudson's Bay Co, trading post a Moosonee. Apart from this flow and a much smaller one north to Churchill and to Schefferville, northern tourism operated on a low level in terms of travel volume, which was reflected in the overall small capacity of overnight services in the northern zones.

The railborne tourists venturing north were of two different categories, a fact which has implications seen from a developemen perspective. On one hand we can identify the typical urban vacationist spending a few days of his vacation time at a lodge or visiting the next town along the railline, often boarding with friends and relatives. The purpose of the journey was that of an excursion, a category that accounts for a substantial percentage of the vacation travel market today and most likely also in the past; a second type was the northern sportsman (fisherman/hunter) lured to northern locations by promotional stories about the big catch, the fine trophy hunt and consequently willing to pay a fair price for the experience. In most market studies this category is in minority and becomes a mass market only in more accessible areas in the south, where recreational fishing and the automn hunt is a popular pastime, at a low price. For the northern destinations expenses from early days were high and could be afforded only by a few; if additional transport costs from the railstop to the camp location were added as well as costs for guides and special equipment it is evident that the potential for large volume tourism is narrow with negative consequences for tourist service operators.

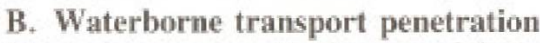
The seaborne penetration has a much longer historical past than the railway services into the north. There existed a coastal shippingtrade along the shores of the Gulf of St.
Lawrence and along Labrador well before the transcontinental railway, and numerous spots accessible by wastal shipping services were famous for sports fishing and hunting before the turn of the century. However, few if any records of travel volume or destination patterns can be traced. We have to wait until the $1920-30$ 's before any recorded information exist that can shed light on the situation.

For centuries the Hudson Bay Co. supply ship journeyed north into arctic waters to re-supply trading posts and bring back pelts to the markets in the south. Undoubtedly occasional tourists were on board for the long journey. However, only in the 1920's are there reports of tourists on board the $\mathrm{S} / \mathrm{S}$ Nascopie as it moved between Montreal and Churchill during the summer weeks. The long duration of the trip - approx. 80 days roundtrip from Montreal was a clear drawback, an obstacle that did not dissappear until 1930-31. when the Winnipeg-Churchill railroad was opened, which made possible at "loop" journey = outbound from Montreal by ship and homebound from Churchill by Rail - reducing total travel time by half, thus making the 
travel experience more palatable in terms of time allocation and total costs. Apart from linking Montreal with Churchill the ship's destination network was impressive as it included a large number of stops along the coast and at islands - Baffin Island, Southampton Island to mention some - In terms of overall contact with the Arctic environment the journey was a success, but even with the reduced travel time and overall costs it was still prohibitive, which was reflected in the tourist volume - only a handful tourists at each voyage. (fig. 3 ). Quite clearly, the $\mathrm{HBC}$ considered freight to be a more reliable source of revenue, which is evidenced by the company's reluctance to replace the supply ship with something bigger and more passenger-oriented. However, from a transport economics perspective the arrangement demonstrates the typical "piggy-backing" of tourist trade to more marginal destinations, where the tourist transport service is secondary to the real economics of the service - freight (the same applies to northbound railway line in Canada and northern Scandinavia).

For the whole era of interwar seaborne tourist travel through the HBC shipping service into Arctic waters only some 100 tourists are officially recorded, a volume figure that reflects the small market segment for such adventures and the limita- tions imposed by the lengthy trip - 40 days and the ticket price - $\$ 300$ : -, to which should be added the fairly substantial expense for the railway ticket to and from the two terminals. One might also consider the stiff competition and in all respects more pleasurable cruise ship services on the market to warmer latitudes, already then, - the Caribbean, Bermuda, in particular, and one realizes that any expansion of the arctic tourist trade would be a risky business venture.

The inconvenience encountered on the cramped ship, the long journey, the expenses and occasional rough weather conditions did not however hold back adventorous americans and canadians. All berths were booked for most journeys.

C. Air services into the North (fig, 4-7). In hindsight it is easy to argue that only the advent of reliable air services has finally opened up the Canadian North and Arctic for tourist travelling on a more substantial scale. It is therefore common to associate northbound air travel with the most recent phase in the penetration of northern Canadian tourist space, following the other two modes of transport in succession. This is a gross misinterpretation of the realities of history, that saw air services into the North start at a much earlier phase - already in

\section{Graphique 3}

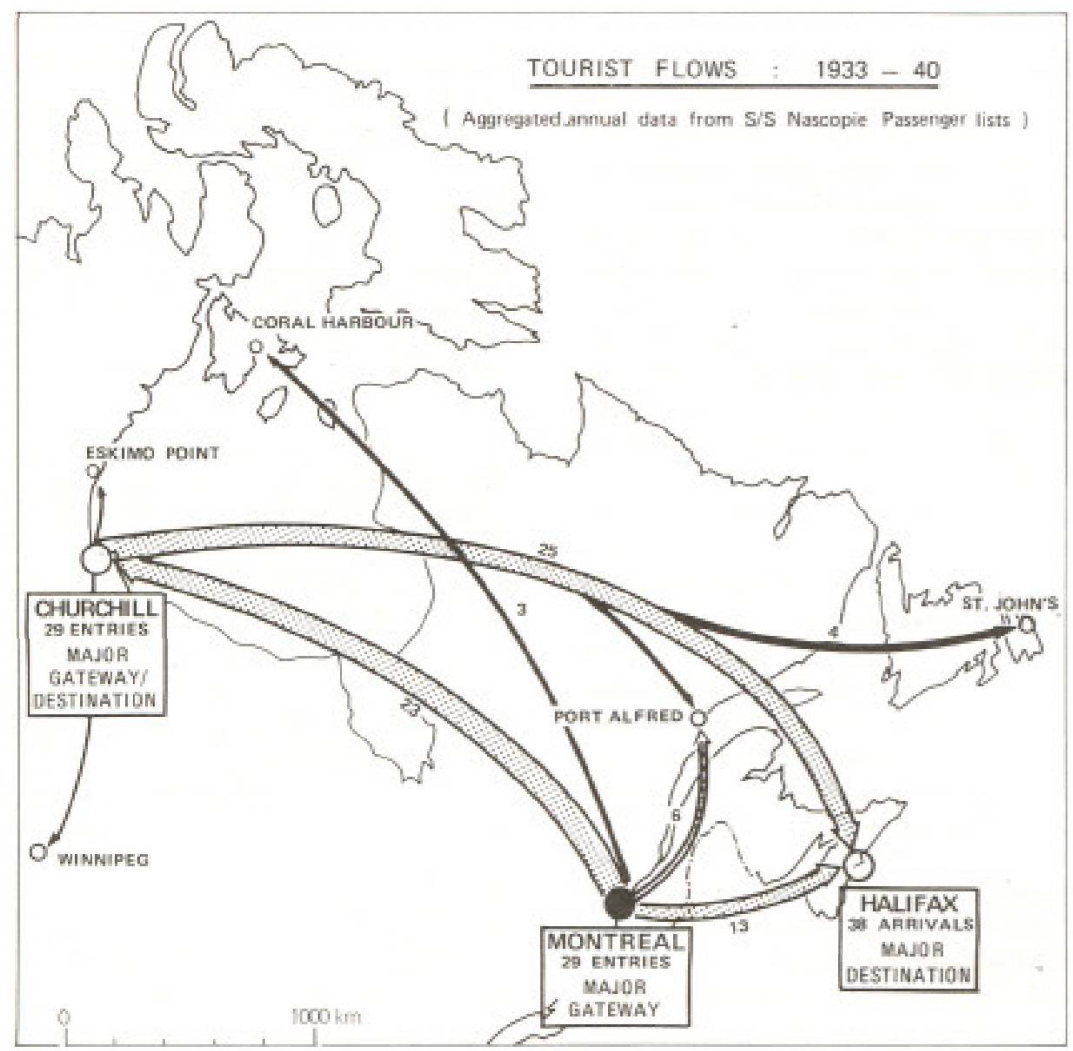

the late $1920^{\prime} \mathrm{s}$ since the initial, rather modest air service networks the airline penetration has been very complete and encompasses today the whole north-south tourist space, an impressive feat considering the geographic circumstances as well as other environmental obstacles - harsh winter climates and long hauls over uninhabited, vast areas.

The air penetration conjures up models of spatial penetration and spatial diffusion that date back to the $1950^{\prime} \mathrm{s}$ and $1960^{\circ} \mathrm{s}$, more particularly the socalled transport penetration expansion concept applied by Taffe, Gould and Morrill on the West African coastland and Interior, a major conceptual contribution to the relationship between changing accessibility, transport linkage development and settlement hierarchy dynamics. The account presented here in the form of a set of stages, demonstrated by the evolution of the Nordair network has considerable similarity with the Gaff-GouldMorrill model, but has no intention to make a "fit" with their findings, basically because the conditions are different - both in terms of geopolitics, economic geography and transport function. The fact that the West Africa study dealt with landbased transport creates also different type of economic impact compared with the nodal, pointlike situation found in the Canadian case, where no contigous setlement surrounds the transport nodes as they are established.

From the point of northbound tourist travel one major obstacle had to be overcome; travel time. Although historically the actual journey has been an important attraction and feature in the travel experience the modern travel market has a much stronger sense of time availability compared with the "not so harried leisure class". The 40 days' tourist trip by the Hudson Bay Co. ship was too long for most people, except for a few. By introducing even small volume air transport accessibility greatly improved, by a more frequent service total travel volume toward a destination quickly surpassed what other modes of transport shipped. Air services could make possible a week's sports hunting/fishing in the Subaretic at a higher cost per day, but on the other hand leaving more days available to make up for the higher expenses than if the tourist had travelled by ship, or even by a combination of slow moving train and local air service. The equation worked, at least in theory, to the advantage of mass tourism.

Three distinct stages of air services into the North and Arctic can be identified. The first stage - the Interwar Era - saw the development of air transport in general in Canada as a by-product of equipment available after W.W.I., and also skilled personnel. Interesting enough, the earliest passenger services had a northbound orien- 


\section{Graphique 5}
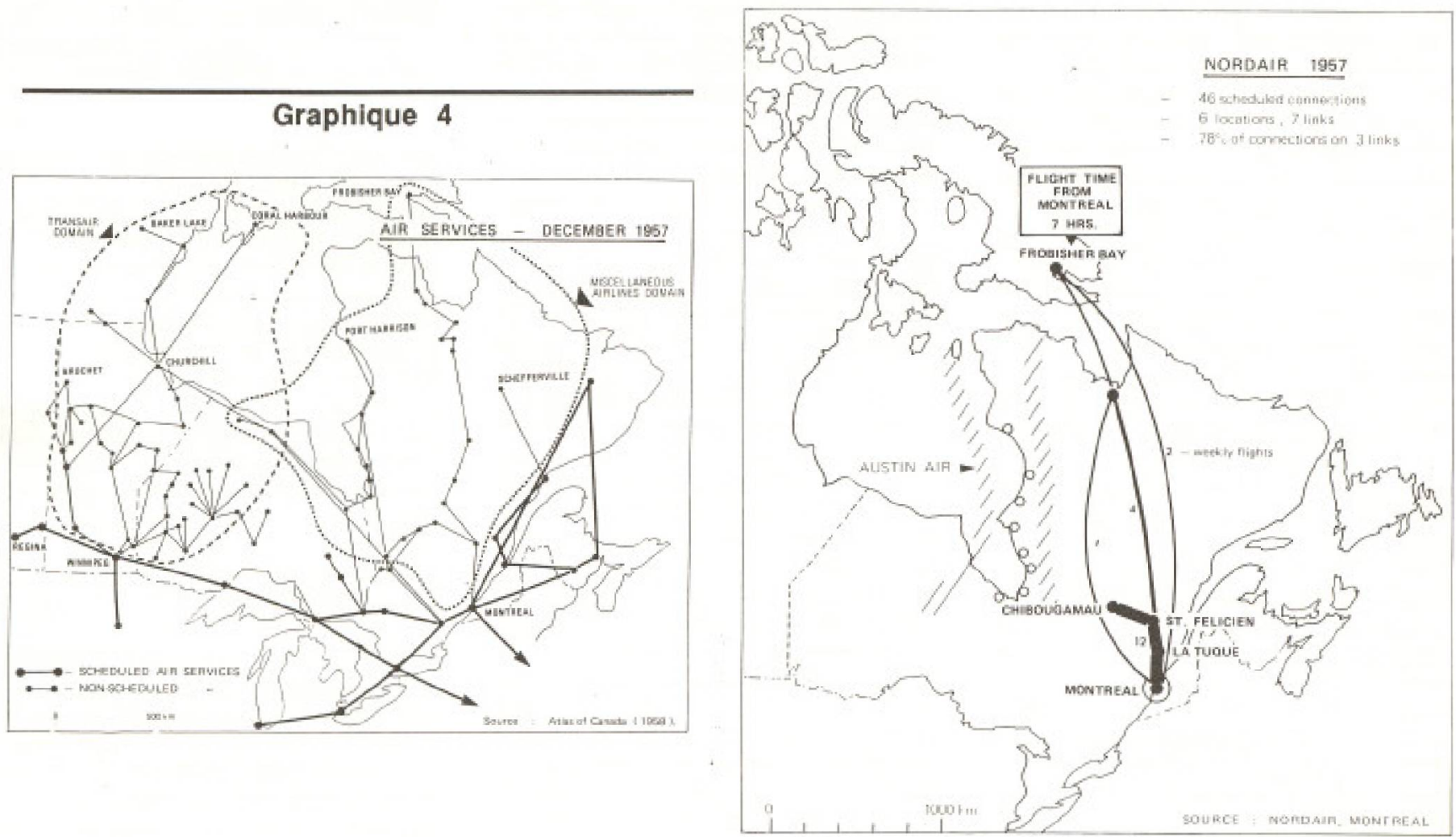

\section{Graphique 6}

\section{Graphique 7}
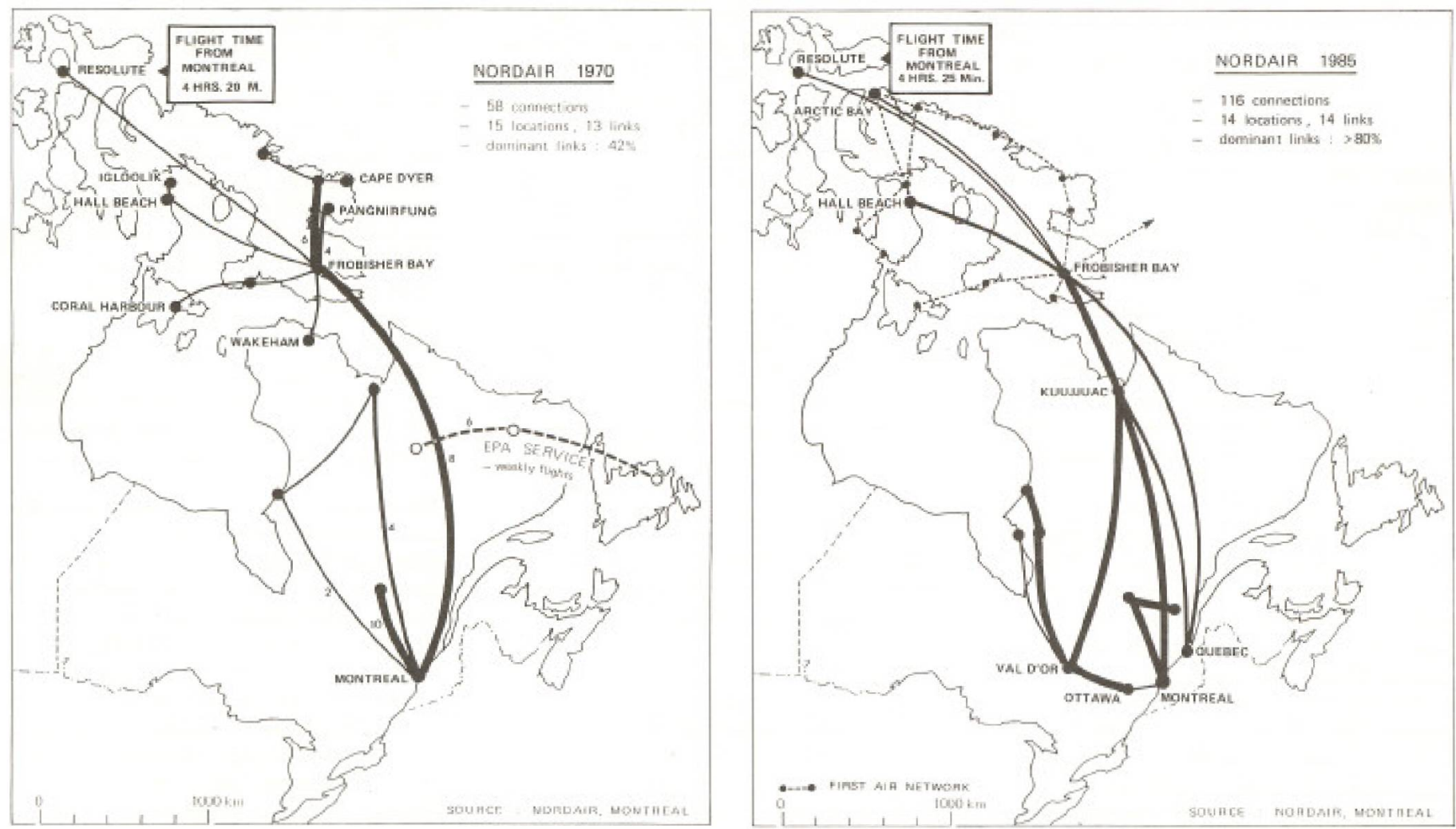
tation, simply because the railway companies had established themselves well in the est-west settlement corridor, leaving the new air services to provide feeder services north from strategic railheads. Already in 1920 was the first northern air link established between Winnipeg and the Pas, some $500 \mathrm{~km}$. to the north. The service consisted of a number of short "jumps" because no aireraft in those days had long-range capacity. In spite of such limitations the total travel time was less than a day. A few years later, 1926 Central Canada Airways was founded by the Richardson family in Winnipeg and at the end of the 1920's substantial areas of Manitoba were accessible by air. As in the case of other transport carriers, the tourist passenger revenues were very minor; the bulk of business was generated by the intense mineral prospecting. Although the air service penetraton reached the Hudson Bay's shore at Churchill already in the $1929 / 30$ season and into the Lake of the Woods area on the ManitobaOntario border about the same time the overall air service penetration catering to tourists was more spatially constricted, but with significant penetration axes established in the mid 1930's. Thus, air links existed to Chesterfield Inlet (NWT) Port Harrison (Nouveau Québec) and Chimo (Ungava Bay) - all run by independent airlines. The most densely developed corridors were along the James Bay coast and Hudson's Bay Eastern shoreline with its numerous native settlements and $\mathrm{HBC}$ trading posts, all serviced by the Austin Airline out of Timmins, (Ont.).

In northern Quebec the air system was poorly developed, the only exception being the long hauls into the Labrador Interior prospecting areas of present day Labrador City-Schefferville en route to Chimo. Admittedly a differentiation must be made between regular service links with southern terminals points; Ilford (Man.) Trout Lake (Ont.) and Sept.Isles (Que.) marked the permanent northern access points, the remaining northern service links being seasonal.

The mid $30^{\prime} \mathrm{s}$ also saw southbound links with the US market, a critical factor for any future tourist market potential being activated, a fact that greatly assisted the development of the northeastern Manitoba fishing lodges around God's Lake-island Lake. - In Quebec the front ran much further to the south simply because the need for air services was weaker, a fact that can be explained by the strong demand for industrial mineral prospecting, which tended to develop overland transport infrastructure as time went by, esp. in the lower North. No doubt, the air services operating out of railheads succeeded in moving the northern front of fishing camps, a few $100-200 \mathrm{~km}$. further north. However, the air service never developed into long haul operations as was the case in Manito- ba. Good fishing could be found closer to home!

The post World War II spatial pattern of air services can be gleaned from the mid 1950 's map. Although the service links have not changed markedly, certain operational improvements had been introduced, which aided the northbound tourist. First, the equipment most commonly used were DC-3:s, which vastly improved both capacity and comfort, and to some degree also speed; second, due to bigger aircraft used the interest in maintaning regular schedules between points of some signifiance increased, which produced a more spatial structure in the services; thirdly, the factor that more than anything contributed to a certain economic stability for a few years was the establishment of northern radar defence installations both in the middle North and in the Arctic (Frobisher Bay, Coral Harbour); an additional stabilizing factor was the massive resource industry developments, esp. in the central Labrador City-Wabush, Schefferville, Fermont, which established urban settlements that both generated and needed air transport services. Thus, the air (service) frontier moved well into the Arctic, with major staging points for services deeper northward centered on Churchill in northern Manitoba and Chimo in Ungava Bay.

Most of the services catered to industry operations accross the North, but some were more directly related to tourism developments: bush pilots transformed their small-sized businesses to tourist outfitter enterprises, because service contracts for mineral prospecting dwindled as mining companies started up production. The Ungava Bay -George River region is a case in point: starting in 1956 and into the beginning of the 1970 's practically all outfitter enterprises that today operate in the region were established, with major concentration along the George River with its fine salmon fishing combined with caribou hunting. - Similarly more tourist-related developments occured in northern Ontario and Manitoba (see map) with difference being that the fishing lodge business did not get air services through piggy-backing on the mining interests, but had to finance them all by their own effort. Thus, the services developed between Winnipeg and the God's Lake -Island Lake area and between Sioux Lookaout and numerous lodge locations some $300 \mathrm{~km}$. to the north.

Clearly, as the 1950's drew to a close, the tourist frontier had shifted sharply northward, encompassing most territory of Nouveau Quebec, with obvious geographic concentration in certain directions such as the Ungava Bay zone; similarly, northern Ontario was being exposed to a deeper penetration in its northwestern corner; in Manitoba, finally, the lake-studded region to the north-west of Lake Winnipeg as well as resource-endowed areas north of the Pas were actively involved in the tourist trade. However, with a few exceptions, the destination pattern never reached into the arctic archipelago area, a move that required new transport initiatives, that were yet to come.

The era of long-range transport penetration (1960-1980's) required different economics and different transport logistics compared with the forces that so far had been at work. One may argue that the airservices provided during the 1950 's were not permanent enough in financial and corporate terms to be able to make the final deep, long-hand penetrations, simply because they often tended to be operating to meet certain limited policy objectives, such as the construction of the DEW line, or the servicing of mineral exploration undertakings. When the objectives were reached by the financiers of the services, the transport contracts were discontinued and so were usually the services.

True long-haul air services over uninhaited, inhospitable land areas, required not only better aircrafts, but also, as size increased, better ground services, better navigational aids combined with some forms of emergency support available. To find sufficient market demand for tourist trips into the high Arctic would be practically impossible and would most likely be available only at prohibitive prices. In lieu of large volume tourist flows the air carriers involved had to find other financial support. Thus, the federal government policies - the Northern Vision combined with geopolitical national considerations were bases upon which long-haul air transport economics at least partially could be positioned.

Few airlines were willing to embark upon this new, hazardous venture, at least in the east. However, those carriers that did so came in the final analysis to fare better than their regional competitiors that opted for the middlenorthern zone with its mining towns and other settlements, that over the years one by one became increasingly accessible by overland transport, as the road network penetrated deeper. There was no risk for competition from road-based carriers in Baffin Island, or in areas north of the Hudson Bay Railwayline in northern Manitoba - not for a long time anyway.

The best example of the air penetration during the 1950 's-1980's northward can be provided through the study of air service development in the Quebec-Ungava BayArctic Archipelago transport corridor, which saw the growth of Nordair from a samll regional carrier to an expert carrier of long-haul cargo and passengers from staging points in the South, esp. at Montreal, but later also at Quebec City and Ottawa. The main characteristics of the Nordair schedule development is an in- 
teresting example of transport strategy applied to an extensive geographic service area, whith two fundamental attributes massive geographic dimensions and little if any regional population. - The company operated originally together with Quebecair typical regional carier networks, linking the interior mining towns and peripheral ports along the Northshore with metropolitan centers. The Nordair original base was in the Lac St.Jean area, from which the service links radiated both south and north tying together a service territory almost of circular shape and with a strong "northern" presence. This network was already in place when the company was formed out of Boreal Airways, its regional predecessors. The 1960 network gave a prominent northern profile, as practiclly all southern points were eliminated, with some major exceptions - the base was shifted to Montreal and the company made the most in revenue terms from the new services to the Val d'Or mining area. Already in the early 1960's the airline flew into Baffin Island (Cape Dyer). The long-haul emphasis is strengthened by oonvenient direct services Montreal - Cape Dyer in the mid-60's and the introduction of "outport" services throughout Baffin Island. The link with Resolute Bay becomes reality, but at a long travel time - seven and a half hour.

The major break-through in the conquering of the long arctic distances occurred around 1970 , when jet aireraft were introduced, halfing travel time while doubling capacity. Timewise the whole of the Arctic moved within an confortable day's journey which in theory should have a positive effect upon travel demand. In addition to the above, the air fare to northern destinations during the $1950 ' s$ and 60 's dropped in relative terms; it remained stable until around 1970 at $\$ 250$ :- return MontrealFrobisher Bay, after which the 1970's oil crises started to affect the overall price levels, including air fares. In 1980 the \$500:level was reached and the fare has since increased further. However, the price increases have on the whole remained either below or on par with the consumer price index for the same period.

\section{Present tourist flow characteristics}

Considering access improvements and relatively modest fare increases, as well as greater market awareness of the potential of tourism into the North - popular new attractions have been established in the form of national parks (Baffin Island), park reserves (Ellesmere Island) - there has only been a marginal increase in tourist influxes. Certain constraints have been at work as well - constraints on potential sports fishing and hunting territories as a result of agreements involving native rights in particular. Consequently, there was no massive expansion of tourist facilities, although northern-arctic tourist programs were in- troduced. However, in terms of pulling in large numbers such schemes usually catered to small parties, leaving only a handful attractions serving mass tourism - the big, impressive hydro installations at LG2, the easily accessible railway terminals at Churchill and Moosonce and up til recently Schefferville, the national park on Baffin Island, and some of the road-acoessible destinations much further south - Manicuagan, Mistassini.

The reasons to the rather modest response in the marketplace to the considerable achievements of the post WWII air transport development rests with the strong, well established attributes in vacation travel behaviour, all of which run counter to the extravagant form of wilderness tourism "arctic style": family vacation travel is dominated by the use of the family car for transport purposes; family destination area preferences are more diverse in the pursuit of recreational activities, that are not available in the singularly wilderness-oriented travel experience supplied by the northernarctic environment; finally, the cost factor, even with the best of air packages, is on a level that hardly attracts large numbers on the national market. A more efficient marketing of the Arctic on the international market might still produce sufficient volume to make northern tourism a more realistic cconomic undertaking compared to what has been the case during most of the decades when it has been possible to travel as a tourist into the Canadian North and Arctic. $f$

\section{Bibliography}

11) Primary sources: all information on the history transport have been provided through Manitoba Provincial Archives (Winnipeg) and through asistance from Nordair. - Date on outfitter/sports camp location were gleaned from the official listings of such facilities prepared by provincial offices of tourism in Manitoba, Ontario and Québec. - The transformation of bush pilot operations in the Ungava Bay region was described to me by Bill May of Bill May and Sons, that have operated in the region since the end of the $1930 \mathrm{~s}$, and as tourist outfitters since 1956.

(2) The concept of tourist space has its origin in articles by W. Christaller, "Some considerations of rourism kocstion in Europe: the peripheral reguons - underdeveloped countries - recreation areas", Regional Science Association: Papers XII. Lund Congress 1963, RSA Papers 12, 1964, pp, 95-105. Note, that a german language paper appeared in Erdkunde 9:1,1955 elaborating on the same theme. - More recently, J.M. Miossec discusses the concept in "Un Modtle de I"Espace touristique". L'Espace Géographique (1977), NO. 6 (1), pp. 41-48 and it has since besen elaborated by numerous authors, but in different geographic siltuations, such as by Jan Lundgren, "Circumpolar towrist space: a geographic camparison of Northem Canada and Northern Swaden", Actes du Con. gròs de I'Association Canadienne des géogra. phes, Trois-Rivieres (1985), pp. 228-245.

(3) Secondary sources: railway passenger statistics are official records from the Ontario Nonthland Realroad and the Iron Ore Company R.ailway Division.
Les tarifs aériens...

(Suite de la page 7)

déréglementation du transport aérien à la fin des années 70 aux États-Unis, les tarifs aériens ne sont plus régis par IATA pour les vols au-dessus de l'Atlantique Nord. $\mathrm{A}$ titre d'exemple, le CCF interdisait les correspondances - c'est en principe un tarif "point à point" -, mais depuis deux ans des compagnies permettent l'interligne.

L'influence des compagnies charters, la forte concurrence, la déréglementation ont obligé, selon monsieur Fortier, les compagnies régulières à développer ce qu'il nomme un "mix de revenus" : des revenus provenant du marché à haut rendement (première classe, classe "affaires") et de celui du "bas de gamme" (les divers tarifs bon marché surtout accessibles aux vacanciers, aux touristes). Cette évolution a été, en fin de compte, à l'avantage général du tourisme de masse mais, à cause des services réduits dans bien des cas, elle a diminué l'expérience sensorielle, parfois mystificatrice du transport aérien. L'avion devient progressivement un "autobus volant" pour reprendre l'expression chère à monsicur Fortier.

\section{Des tarifs universels}

Enfin, dernier trait caractéristique, les tarifs bon marché au-dessus de l'Atlantique Nord ne reposent pas sur une approche clientèle (sauf le tarif jeunesse qui est limité à moins de 22 ans). Sur d'autres destinations en Europe, on a développé des tarifs "jeunes" des tarifs "Etudiants" nettement plus avantageux. Il y a aussi des tarifs "familles", des tarifs "personnes âgées" ".. L'appro-

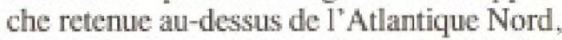
au grand mécontentement de monsieur Zvi Ravon, secrétaire général de la FIYTO ${ }^{5}$ est celle des tarifs avec restrictions accessibles à tous ceux qui peuvent respecter ces restrictions, ce qui n'est pas toujours à l'avantage des jeunes de plus de 22 ans qui souhaitent partir sur de longues périodes...

Une évolution n'est-elle pas souhaitable en cette matière pour tenir compte des caractéristiques propres à chaque groupe de clientêle? Les compagnies aériennes semblent peu réceptives cependant à emprunter cette voie! +

\section{Notes et roférences}

(1) Bulletin OACI, juin 1981.

(2) form

(3) JOPPE, Marion, L'intervention de l'État dans le domaine du tourisme, thèse de doctorat sous la direction de MM. René Baretje et Francois Sevoin (CHET - Aix Marseille), Édition Danisa, Paris, 1983.

(4) IATA ou AITA: Association du transport aerien internationsl

(5) M. Ravon, secrataire général de la Fédération internationale des organisations de tourisme jeunesse (sigle anglas; FIYTO) a longtemps fait pression sans succés aupres des transporteurs nordaméricains pour que soit créé un vêtrițable tarif pour les jeunes travailleurs avec une limite d'age repoussée. 